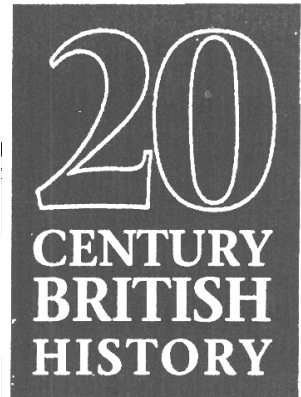

Editors: Ross McKibbin, St John's College, Oxford John Rowett, Brasenose College, Oxford Review Editor: Ewen Green, University of Reading

Founded in 1990 on the premise that contemporary British history was relatively ill-served by existing periodical literature, Twentieth Century British History has led the initiative to meet that need with its wide range of lively and provocative articles.

Moreover, whilst remaining eclectic and interdisciplinary in scope, and examining the British experience within an international comparative context, the journal has established an enviably high reputation for its scholarly articles in the areas of social and economic policy, and public and social institutions.

Features of Twentieth Century British History, include original articles by younger as well as established scholars, a highly regarded reviews section, debates, archive surveys, and reviews of historical work in other media.

Recent and forthcoming articles include:

Keith Burgess Youth Unemployment Policy During the 1930s; John Buckley Contradictions in British Defence Policy 1937. 1939; Brian Harrison Thatcherism and the Intellectuals; Dianne Kirby The Church of England and the Cold War Nuclear Debate; Jane Lewis Public Institution and Private Relationship: Marriage and Marriage Guidance, 1920-1968; John Stewart Ramsey MacDonald, the Labour Party, and Child Welfare 1900-1914; Charles Webster Studying Whitehall.

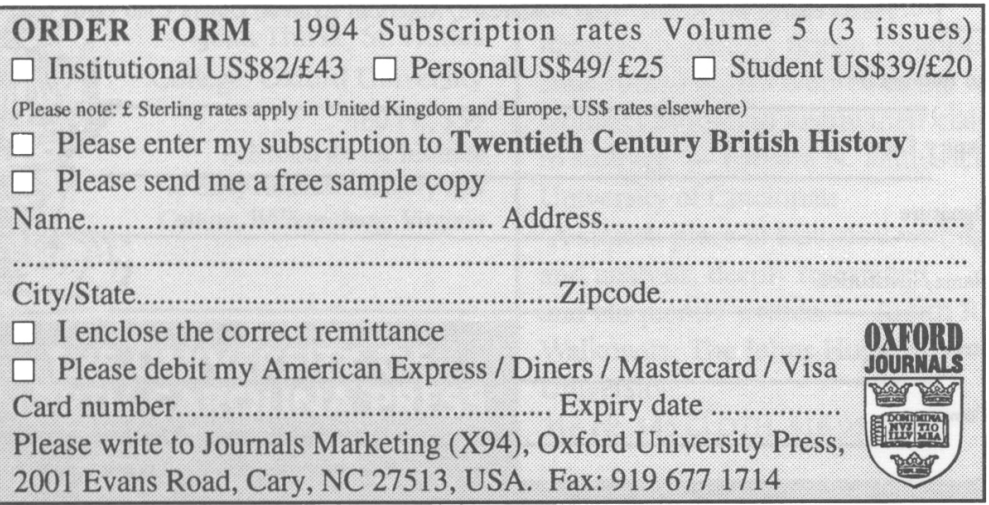




\title{
Parliament and the Atlantic Empire
}

\author{
Edited by Philip Lawson
}

S ince the loss of the American colonies in 1783, the history of Westminster and Colonial Parliaments have been something of a lost child in the BritishAtlantic past. This collection of papers examines the historiography as well as the history of the relations between the legislatures of the thirteen American colonies, Quebec and the British West Indies, and Westminster in the seventeenth and eighteenth centuries. A more global view is taken of the English-speaking Atlantic world and parliamentary and legislative concerns are brought out of their parochial confinement.

The contributors are the editor, Jack P. Greene, David Milobar, Ian K. Steele, and Michael Watson. This is a special book issue published as part of the Parliamentary History journal, volume 14.

Philip Lawson is the Department of History at the University of Alberta. Paperback March $\$ 20$

How to order Parliament and the Atlantic Empire

Please return this form with your payment to:

Kathryn MacLean, Edinburgh University Press,

22 George Square, Edinburgh EH8 9LF, UK

Please send me copies of Porliament and the Atlantic Empire@\$20 (please add $\$ 4$ for postage and packing)

Please charge my Access/Visa/Mastercard/American Express/Diners Club card

Ac number

Expiry Date

Signature

Name/Institution

Street

Town

Country

Zipcode 


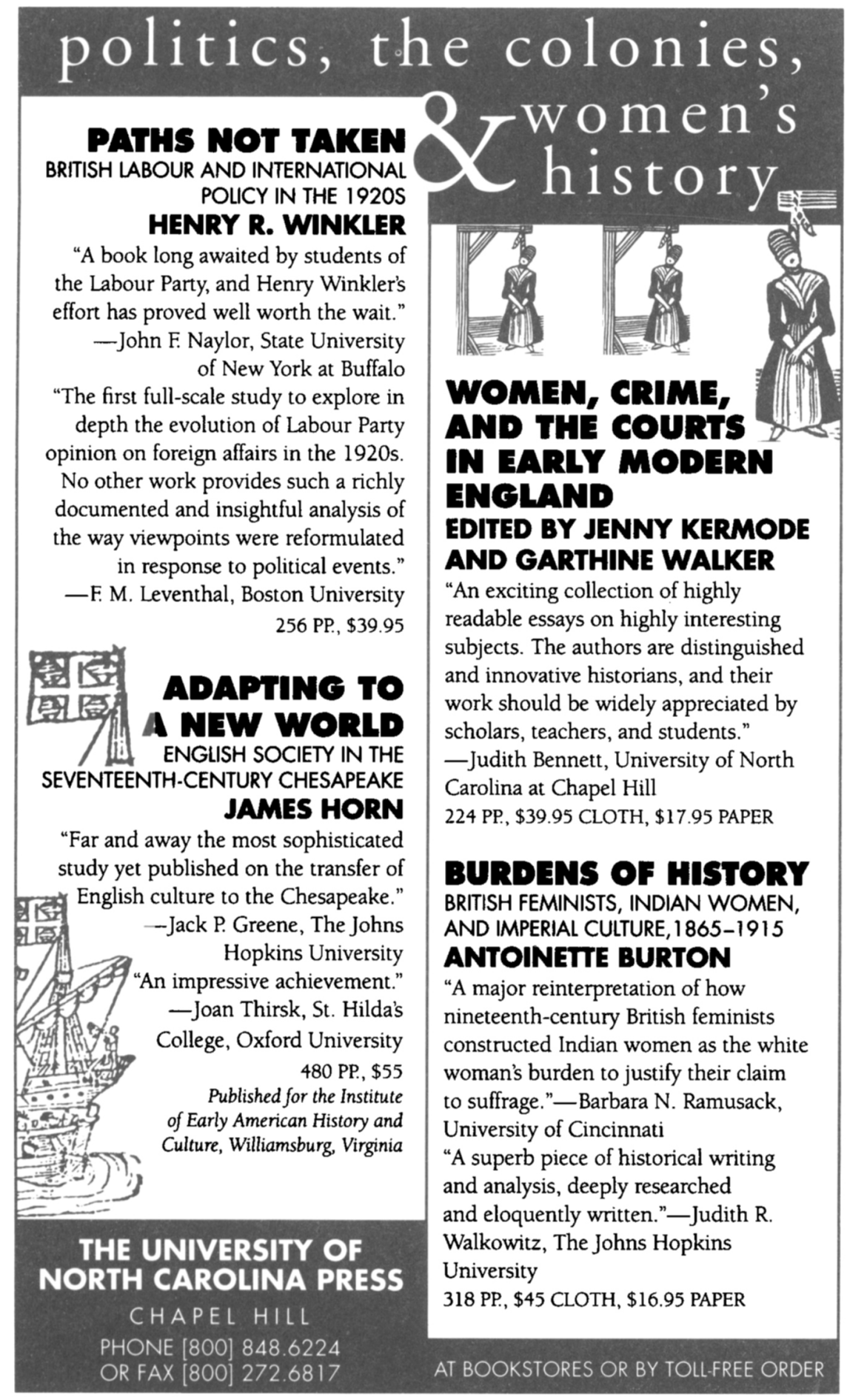




\section{Henry IV \\ Bryan Bevan}

Henry of Bolingbroke, born at Bolingbroke Castle in Lincolnshire, about 1366, son of John of Gaunt ("time-honored" Lancaster) and his beautiful heiress first wife Blanche of Lancaster, was one of the most important noblemen of the later 14th century. This book examines the history behind Henry's usurpation of the throne, his constant efforts, politically and on the battlefield, to preserve his kingdom, and his triumphs and controversies.

$1994 \cdot 166$ pp. $\cdot$ illus.

$\$ 39.95 \mathrm{cl} \cdot \$ 16.95 \mathrm{pb}$.
Fish and Chips and the British Working Class, 1870-1940

\section{John K. Walton}

Walton traces the origins of what was by 1914 an important national industry - the fish and chips trade. He charts the economic, social and political context of the trade, including themes such as recruitment patterns, methods of working, the role of women in the food industry of the period, and the aims and effectiveness of trade organizations.

$1994 \cdot 210 \mathrm{pp} \cdot \cdot \$ 19.00 \mathrm{pb}$

Leicester University Press Book

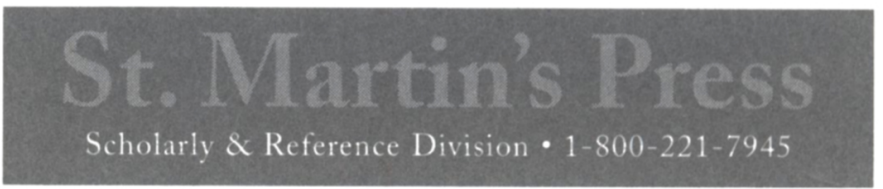

\section{Post-Medieval}

\section{Archaeology in Britain}

Revised Edition

\section{David Crossley}

The archaeology of the period 1500-1800 has recently received specialist attention, but this book complements the specialized studies with field evidence. Crossley surveys the current state of post-medieval archaeology and presents a guide to the literature the rural landscape, urban archaeology, fortifications and industry.

1994 • 344 pp. • illus. • \$25.00 pb.

Leicester University Press

\section{Sex In Georgian \\ England}

Attitudes and Prejudices

from the 1720 's to the 1820 's

\section{Arnold P. Harvey}

Using the evidence of medical texts, trial records, government statistics, pamphlets, autobiographies, novels, poems, plays, dress fashions, pornographic engravings and paintings by members of the Royal Academy, this book shows how the 18th century contructed the stereotype of femal purity and passivity which was to be inherited by the Victorians.

1994 • 216 pp. • illus. $\$ 45.00$ 